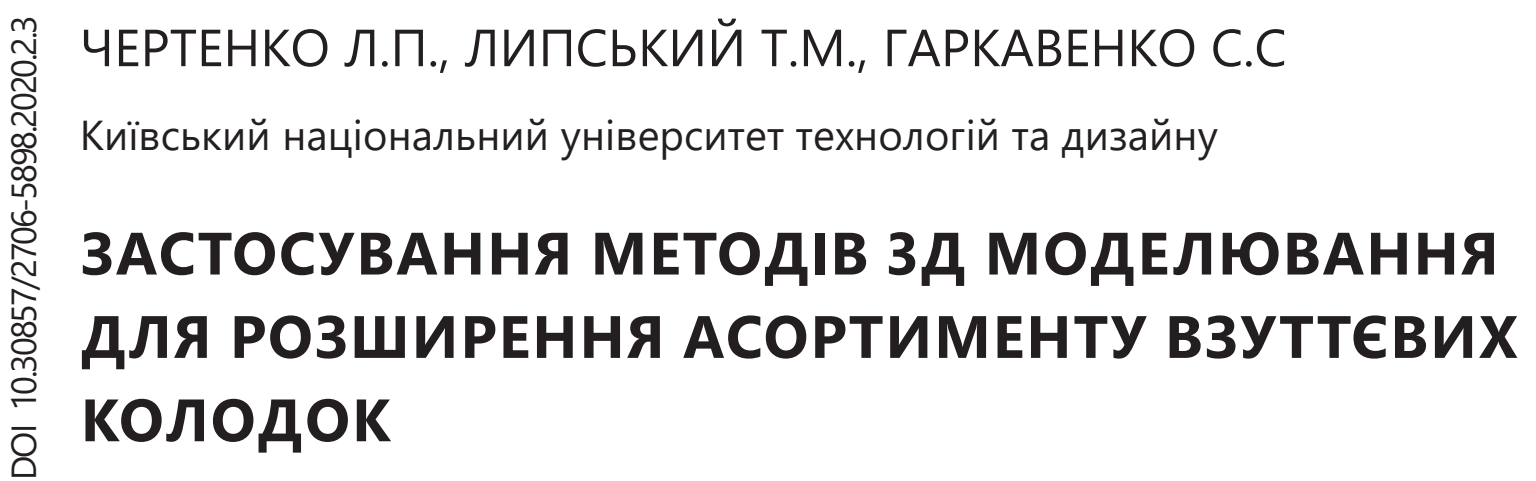

Взуттєва колодка визначає внутрішню форму взуття. Таким чином, одна з першочергових задач, що виникають при впровадженні САПР для проектування взуття, полягає в поліпшенні методу проектування складної поверхні колодки (тобто, внутрішньої форми взуття), щоб забезпечити ефективне використання функцій САПР для цієї мети. Різноманіття сучасних форм колодок ускладнює завдання розробки їх ергономічних параметрів. Один із способів вирішення цієї проблеми - розробка комбінованих форм колодок, що складаються з раціональної задньої (основної) частини, яка включає п'яткову, геленкову і пучкову частини, та змінної фігурної ділянки носка. Це рішення допоможе реалізувати завдання розширення асортиментного ряду колодок на основі базових ергономічних форм.

При цьому проблема з'єднання двох різних частин складної просторової форми колодки вирішується за допомогою використання методів Блендінга, Морфинга і Побудови стикувальних поверхонь в середовищі програмного забезпечення PowerShape.

\begin{abstract}
Mema pоботи: Вдосконалення асортименту взуттєвих колодок за допомогою використання графічних функцій Зд моделювання

Наукова новизна. Метод моделювання ергономічної форми взуттєвої колодки заданого стилю шляхом поєднання двох окремих частин різних базових форм за допомогою функцій поверхневого та гібридного моделювання програмного забезпечення PowerShape.

Практичне значення. Розробка нових форм взуттєвих колодок на основі перевірених ергономічних конструкцій забезпечує гарне поєднання комфорту та естетичного дизайну, створюючи передумови для практичного втілення ідеї універсальної взуттєвої колодки зі змінною носковою частиною.
\end{abstract}

Ключові слова: взуттєва колодка, форма колодки, поверхневе моделювання, зд дизайн, задня частина колодки, носкова частина, морфінг, блендінг, поверхня стиковки.

\title{
APPLICATION OF 3D MODELING METHODS TO EXTEND THE RANGE OF SHOE LASTS
}

CHERTENKO LP, LYPSKYI TM, GARKAVENKO SS

Kyiv national university of technologies and design

A shoe last determines the inner form of a footwear. Therefore, one of the primary tasks that arise while introducing CAD of footwear is to improve the method of designing the complex surface of the shoe last (the inner form of a shoe) to provide the efficient use of CAD functions for this aim. The variety of modern shapes of shoe lasts complicates the task of developing their rational parameters. One of the ways to solve this problem is developing a combined shoe last that has a scientifically sound back part which includes the heel, instep and ball area, and the convertible toe part. This solution will help to fulfill the task of expanding the assortment range of the shoe lasts using basic ergonomic shapes At the same time, the problem of joining two different parts of a complex spatial shapes of the last is solved by using the methods of blending, morphing and construction of joining surfaces in the PowerShape software environment

Purpose. Improving the range of the shoe last shapes using 3D modeling features.

Scientific novelty. The method of modeling the ergonomic shape of a shoe last of the necessary style by combining two parts of different lasts using the surface and hybrid modeling features of PowerShape software. 
Practical value. The development of the new last shapes based on the tested ergonomic designs ensures a good combination of comfort and aesthetics, creating the preconditions for the practical implementation of the idea of a universal last with a replaceable toe part.

Keywords: footwear last, shoe last shape, surface modeling, 3D design, shoe last back part, toe part, morphing, blending, joining surface.

Today, according to various sources, from 50 to $70 \%$ of the adult population have foot abnormalities and deformities. Among women, the prevalence of foot pathologies such as hallux valgus, curvature of the toes, trauma and deformation of the nail plate, hypertrophy of the head of the first metatarsal bone, as well as corns are mainly the result of wearing the unsuitable and non-ergonomic shoes. Incorrectly selected or improperly designed shoes are a major factor in the development of structural disorders of the foot such as hallux valgus and the deformity of toes [1]. Why are we wearing uncomfortable shoes in the 21st century?

Modern footwear market is characterized by the diversity in shapes, forms, and peculiarities of design. With such an extensive variety of shoe last shapes, it is very difficult to distinguish the rational ones that would fit the parameters of the feet and meet the requirements of the target consumer segments since most designers create the shoe lasts arbitrarily, without taking into account the regional features of the feet, comfort requirements, etc.

Many publications are devoted to determining the ratio of the feet as well as shoes parameters and choosing the suitable shoes $[2,3]$. The majority of the scientific approaches to designing the complex shape of the customized shoe lasts can be narrowed down to the following directions:

1) Selection of the fit last based on the comparison of the physical parameters of a foot and a last $[4,5]$.

2) Comparison of the customer's foot with the statistical foot and using the differences for the modification of the original last shape [6].

The simplest way to design a new shape of the last in 3D graphic space of modern CAD software is to modify the last of the suitable parameters and required style. The main focus in many publications is on developing the ways to determine the best degree of compliance of a last from the available library or database using 3D scanning of the customer's foot with the help of geometric comparison [7] or based on accordance to the most important anthropometric parameters [4].

$\mathrm{Ma}$ and Luximon [5] suggested creating a 3D map of the last with the help of which the levels of correspondence and inconsistency of the shapes of the surfaces of the foot and the last are estimated. The author proposes to choose the most suitable for the customer shape with the use of such a map and then to work on improving its surface in accordance with the features of the customer's foot and design. Mohimaru [6] proposes to proceed from a standard last designed on the basis of the typical average foot when developing an individual last The difference between the shapes of the typical average and individual feet can be represented as a spatial distortion of the control points of the spatial deformation grid with the help of which the basic shape of the last is further adjusted. Such methods can be effective in the development of orthopedic or preventive footwear. However, there are a number of disadvantages in their practical implementation when designing elegant fashion shoes in which one of the most important factors is the aesthetic perfection of the shape with a huge number of different original shapes. The situation with elegant fashion shoes is complicated due to the fact that fashion changes every season. Due to this, every season, designers are offering more and more new lasts which, again, need to be adapted to the consumers' feet measurements. A good solution for the problem of updating the range of the existing shoe lasts while meeting the requirements of the ergonomics of their shapes can be designing the shoe last models based on joining the individual parts, where the basic back part of the last corresponds to the foot parameters, and the toe part is modeled arbitrarily according to the style and design.

The main problem that arises when developing the combined forms of a shoe last in the graphic 3D CAD software environment is joining of individual parts of the last. A number of publications [8-10] are devoted to this problem, the authors suggest using the special 3D modeling features of Blending and Morphing for this purpose.

The paper [8] studies the continuity of the ruled surfaces constructed by linear interpolation between two pairs of continuous curves. The study [9] includes information about the application of morphing techniques introduced a method that allowed two objects to be morphed using variable interpolation. In his work, Li [10] solves the problem of combining the toe and back parts of different lasts in a 3D virtual space of CAD software using the combination of the methods of morphing and blending in order to automatically obtain a smooth filling surface in 
a controlled way

In this paper, we set out to explore the possibility of expansion of the range of shoe lasts creating new last shapes on the basis of the ergonomic back part of the last and the different samples of the toe part using CAD 3D modeling features. Methodology. The models of basic shoe last shapes were obtained by 3D scanning of physical samples using a specialized foot in a 3D scanner [11] and saved as a polygonal mesh in STL format. For further work on the design of the new last forms, the Power Shape software was used.

The main back part of the shoe last includes a heel part, waist and instep area, as well as a ball part and it is based on the foot parameters [11] (Fig. 1), while the replaceable toe part depends on the design and is constructed as a 3D sculptural designer shape.

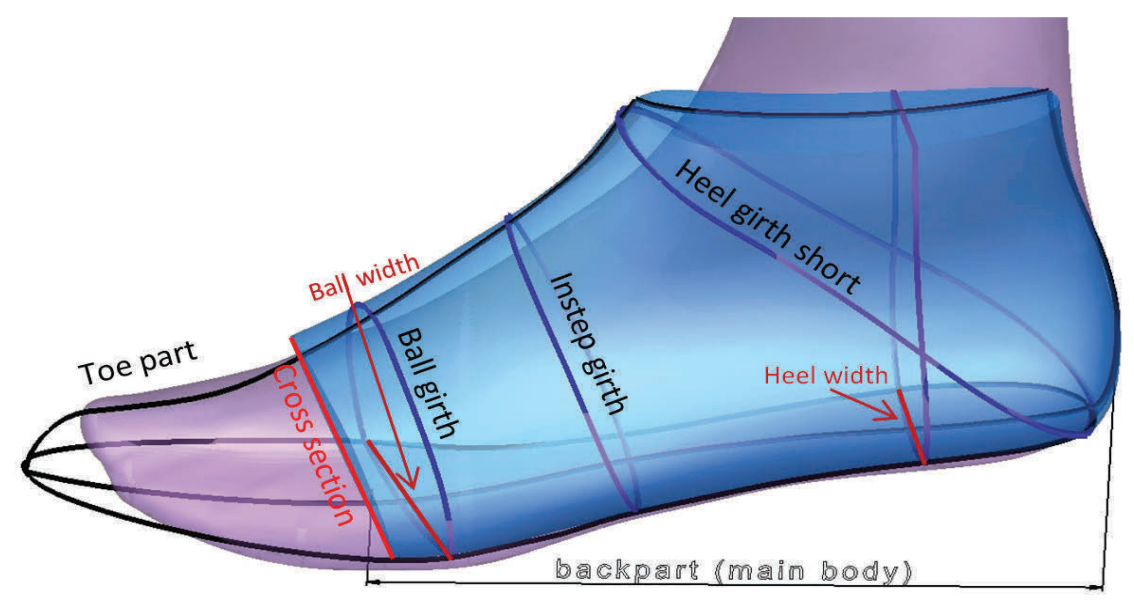

Figure 1. 3D Shape of the Shoe Last with an Ergonomic Back Part and a Replaceable Toe Part

The variety of shapes of the main and toe parts of the lasts is determined by the following factors: - For the main back part: last size and width, type of shoe, heel height, the peculiarities of morphological structure of the customer foot, etc.

- For the toe part: design, shoe style, features of the shape of the toe region of the foot, height of the first and the second toes.

Research Results. To create the new shoe last shapes, we first of all needed to clip the last models from the virtual database into two main parts. To do this, we first compared the lasts with each other, aligning them with respect to the common coordinate system, while the toe parts were oriented in the same way, and the heel part was raised to the required height. All the studied lasts were of sizes 37 and 38. The cutting plane was located vertically in relation to the last shape at a distance of $0.8 \mathrm{~N}$ along the inner feather edge and at the distance of $0.73 \mathrm{~N}$ along the outer feather edge (Fig. 2).
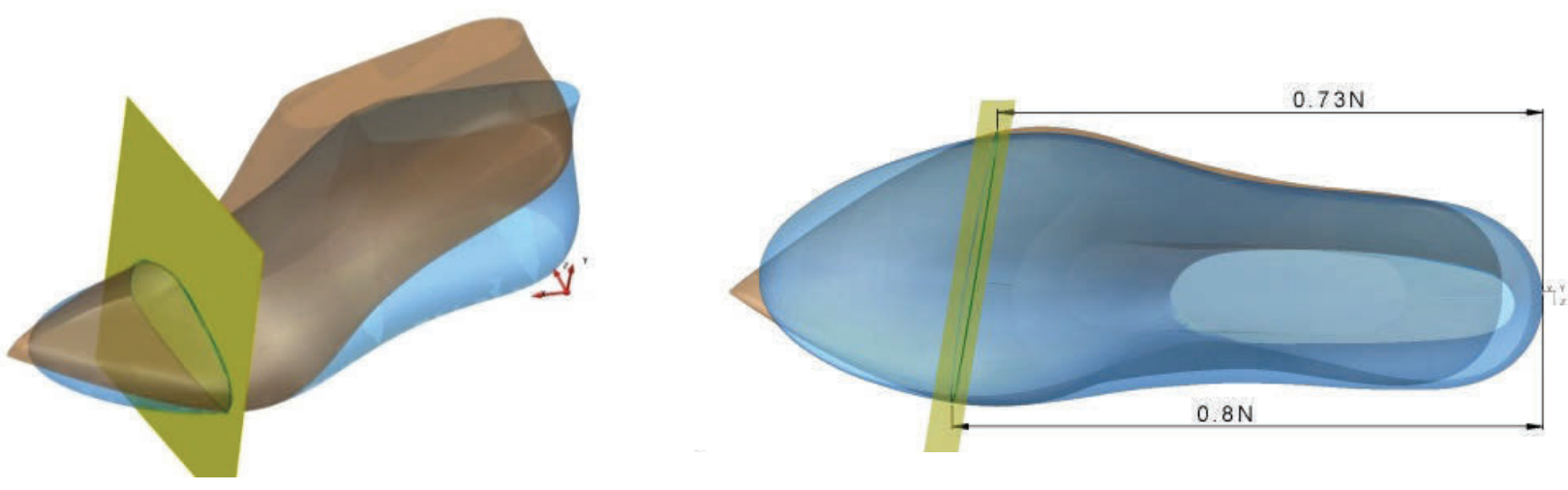

Figure 2. Comparison of the Shoe Last 3D Models and the Design of a Cross Section 
The created virtual database of the last models includes 45 lasts for women's shoe sizes 37-38 (which corresponds to a foot length of 240-250 $\mathrm{mm}$ ) of different styles and with various heel heights (Tab. 1).

Table 1. The Number of the Examined Shoe Last Models of Various Styles

\begin{tabular}{|l|c|c|c|c|}
\hline Toe shape $\backslash$ heel height & $5-20 \mathrm{~mm}$ & $21-50 \mathrm{~mm}$ & $51-70 \mathrm{~mm}$ & $71-100 \mathrm{~mm}$ \\
\hline Oval & 4 & 3 & 5 & 4 \\
\hline Pointed & 0 & 2 & 4 & 5 \\
\hline Square & 0 & 1 & 3 & 2 \\
\hline Anthropometric, round & 3 & 3 & 2 & 4 \\
\hline
\end{tabular}

In the work we have carried out the research of the main parameters of $3 \mathrm{~d}$ models of the shoe lasts (Fig. 1) from a virtual database (Tab. 2)

Table 2. Main Parameters of the Last Models Measured on 3D Foot Software.

\begin{tabular}{|l|c|c|c|c|c|}
\hline Parameter & $\begin{array}{c}\text { Average } \\
\text { Value } \mu\end{array}$ & $\begin{array}{c}\text { Minimum } \\
\mathrm{min}\end{array}$ & $\begin{array}{c}\text { Maximum } \\
\mathrm{max}\end{array}$ & $\begin{array}{c}\text { Absolute Dif. } \\
\text { between the Min } \\
\text { and Max, } \Delta\end{array}$ & $\begin{array}{c}\text { Standard } \\
\text { Deviation } \sigma\end{array}$ \\
\hline Last Bottom Length, mm & 258.87 & 247.9 & 268.2 & 21.7 & 10.72 \\
\hline Ball Girth, mm & 223.25 & 216.1 & 228.8 & 12.7 & 4.65 \\
\hline Instep Girth, mm & 229.18 & 217.5 & 237.4 & 19.9 & 9.20 \\
\hline Ball Width, mm & 83.35 & 80.9 & 88.7 & 7.8 & 2.91 \\
\hline Heel Width, mm & 55.11 & 53.6 & 57.2 & 3.6 & 1.85 \\
\hline Heel Girth (short), $\mathrm{mm}$ & 318.24 & 304.3 & 332.6 & 28.3 & 12.45 \\
\hline
\end{tabular}

The measurement results showed a significant difference in the parameters of the shoe lasts. The aim of this work is to investigate the possibility of exchanging toe parts between different forms of the last models with different parameters.

The main preparatory steps before the process of creating a new shoe last shape from different parts using the CAD 3D modeling feature include the following:

1) Selection of the shoe lasts for the main body and for the toe part.

2) Comparison of the geometric parameters of the selected individual parts of the shoe lasts.

3) Scaling the toe part in the accordance with the main part.

4) Creating the cross sections.

5) Selection of the modeling method for joining different parts of the last.

Based on the analyzed publications and on the practical experience of modeling a complex spatial shoe last shape with the PowerShape features, it is possible to formulate the following methods for joining two separate 3D elements into a single surface of the shoe last:

Morphing [8]. Transformation that converts (or morphs) one shape into another through a seamless transition.

Blending by the cross sections [7]. Design of an intermediate section between two existing ones by a gradual transition from one form to another in cross-sections.

Filling the area between the individual parts of the form with a surface according to control curves [9]. Designing an intermediate surface section between the two existing ones by a wireframes, which are constructed taking into account the direction of the tangents and the curvature of the surfaces to be joined.

When combining parts of the shoe lasts with close physical parameters at the joining area, morphing feature can be applied, which is the 
simplest solution, since it does not require any additional geometric constructions. It is necessary to ensure a smooth transition from the shape of the back part of the last shape to the toe part. To achieve this, we need to use PowerShape features of Morphing of the Surface or Morphing of the Mesh from the curve of the main part to the respective curve of the toe part and apply a limiting plane at the distance of $8-10 \mathrm{~mm}$ from the sectional plane (to avoid deformation of the main part of the last during morphing) (Fig. 3).

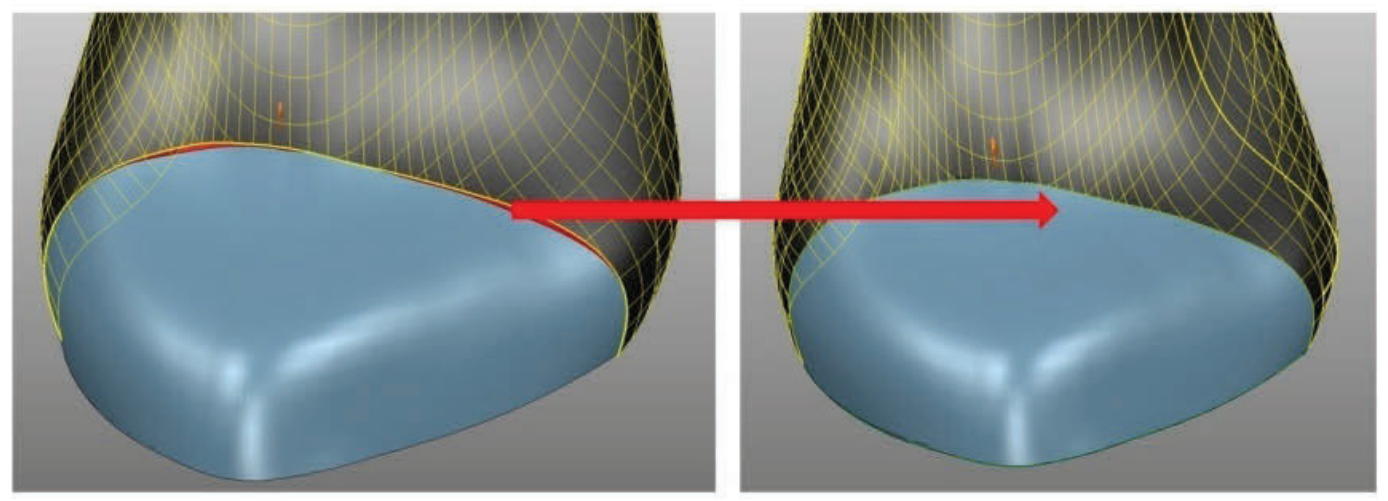

Figure 3.Using Morphing for Adjusting the Area of the Surface of the Main Part of the Last to the Contour of the Joint

In fact, if we need to join the last parts of different shapes of the cross sections, providing a smooth transition without deforming the original sections, then the Blending of Surfaces by cross-sections (Fig. 4) can be used.

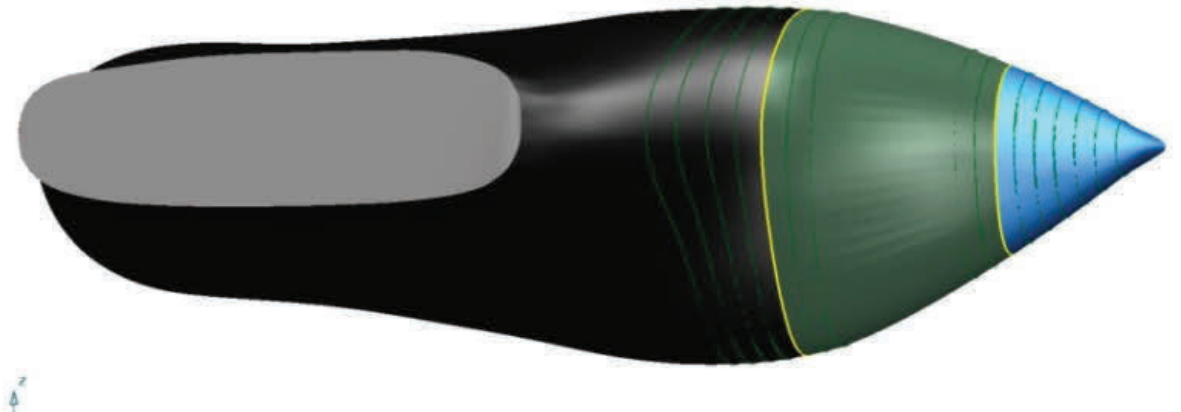

Figure 4. Using the Blending by Cross-Sections Feature for Designing the New Last Shape

However, sometime the configuration of the toe cross section differs significantly from the cross section of the designed last and there may arise the situation when Morphing and Blending by the cross sections doesn't provide the smooth transition from the back part of the last to the toe part (Fig.5).

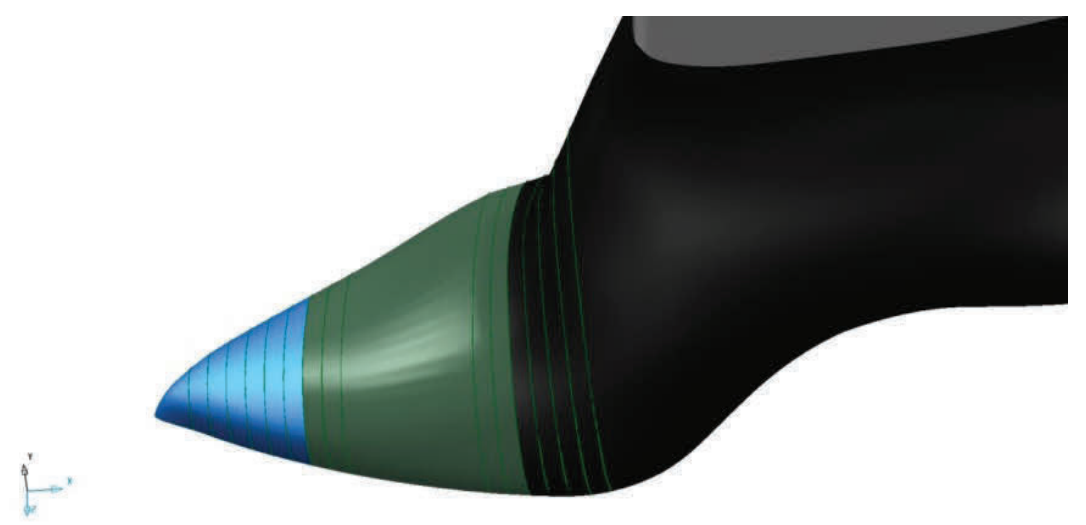

Figure 5. Surface Distortion during Blending by the cross sections due to a Significant Change in Surface Curvature 
And then it becomes necessary to change the configuration of the joining surface. The Morphing and Blending features do not provide this option. In this case, it is necessary to resort to the method of designing a surface named From Network using wireframe curves, which have the ability to be edited by points. The wireframe of the curves of the joining surface is constructed with reference to the base parts

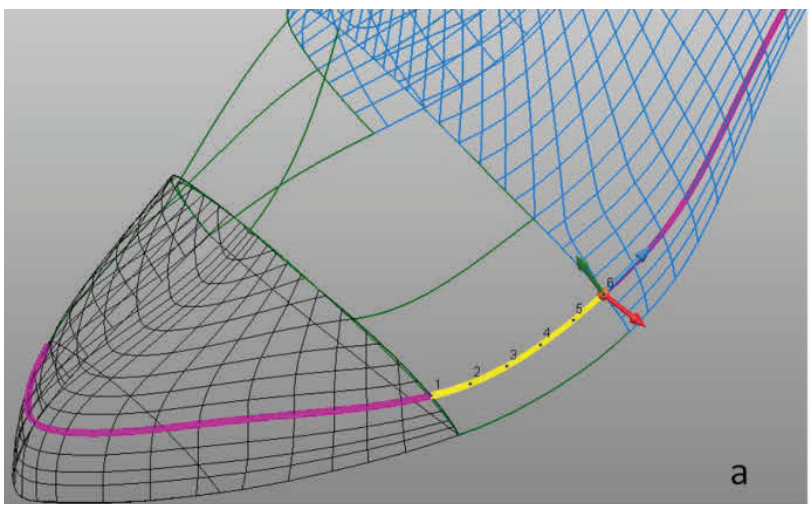

of the last (back part and toe part) (Fig. 6a) ensuring the smooth joining of individual parts of the form with this surface (Fig. 6b), because construction of the missing area is going on by interpolation of the surface by curves, taking into account the smoothness of the shape. The wireframe curves are constructed on the basis of unidirected curves of the surfaces of the toe and the back parts of the last (Fig. 6a)

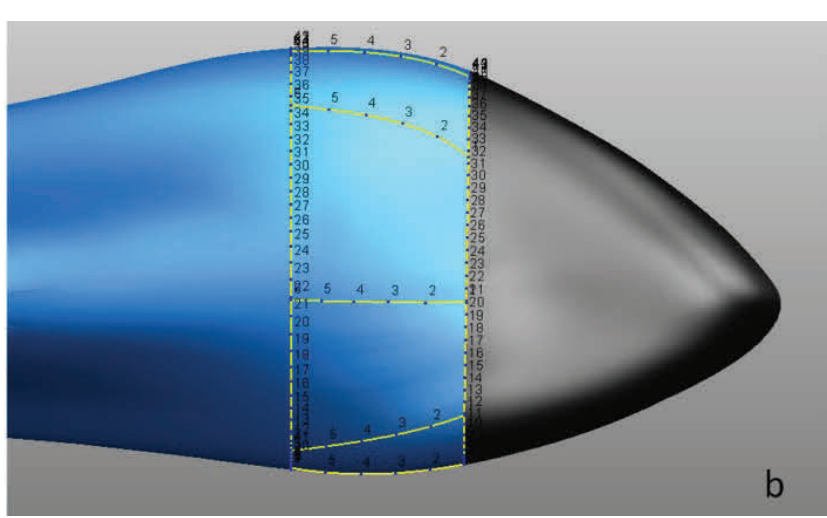

Figure 6. Designing the Intermediate Section between the Toe Part and the Back Part by From Network Method Using Wireframe Curves

Conclusion. The experiment carried out in this work on modeling the new shoe last forms demonstrated the effective use of the features of the PowerShape software for this purpose. In this case, the ergonomics of the new last forms can be achieved due the use of the rational parameters of the base. The toe part is replaced depending on the desired style of the shoe.

To join the toe and base (back) parts of the lasts, the methods of Morphing and Blending are used,

\section{References}

1. Foot Health and Shoewear for Women. Carol, F. s.l. // Clinical Orthopedics and Related Research.-2000, Vol. 372.

2. Witana CP, Feng J, Goonetilleke RS Dimensional differences for evaluating the quality of footwear fit. // Ergonomics. - 2004, 47(12). - P. 1301-1317. doi: 10.1080/00140130410001712645:

3. Au EY, Goonetilleke RS. A qualitative study on the comfort and fit of ladies' dress shoes. // Appl Ergon. - 2007, 38(6). - P. 687-696. doi:10.1016/j. apergo.2006.12.002

4. Wang CS. An analysis and evaluation of fitness for shoe lasts and human feet //Comput Ind. -2010, 61(6). - P. 532-540. doi: 10.1016/j.compind.2010.03.003

5. Ma X, Luximon A, Zhang YF The Application of Toe-deletion and Ankle Deformation Technique in Shoe Fitting Assessment // PROCEEDINGS of the HUMAN FACTORS and ERGONOMICS SOCIETY 55th ANNUAL MEETING, 2011. - P. 1644-1648. doi: 10.1177/1071181311551343

6. Mochimaru $M$, Kouchi $M$, Dohi M. Analysis of 3-D human foot forms using the Free Form Deformation which allow us to achieve the smooth joining of complex shapes and sections of various curvatures.

A shoe last is a three-dimensional solid part of a complex irregular shape, which is difficult to design with standard 3D modeling functions. At the same time, the toe box is a much simpler shape that can be wireframed and designed without reverse engineering.

method and its application in grading shoe lasts. // Ergonomics. - 2000, 43(9). - P. 1301-1313. doi: 10.1080/001401300421752

7. Zhao J, Xiong S, Bu Y, Goonetilleke RS. Computerized girth determination for custom footwear manufacture. // Comput Ind Eng. - 2008, 54(3). - P. 359-373. doi: 10.1016/j.cie2007.07.015

8. Kouibiaa A, Pasadasa M., Sbibihb D., Zidnac A, Belkhatirb B. Geometric continuity C1G2 of blending surfaces. // Computer-Aided Design. - 2013, Vol. 45, Issue 3.- P. 733-738.

9. Turk G. and Obrien J.F. Shape transformation using variational implicit functions.// SIGGRAPH '05. - 2005. - P. 13-20.

10. LiG and Joneja A Gap Filling Using a Blend of Morphing and Extension with Application in Footwear Design. // Computer-Aided Design \& Applications. - 2005, Vol. 2.-P.243-252. doi: 10.1080/16864360.2005.10738372

11. Lypskyi TM, Garkavenko SS, Chertenko LP. Rozrobka metodu proektuvannia kolodokzi zminnoiu noskovoiu chastynoiu. Povidomlennia 1. // Bulletin of KNUTD. 2017, No3 (110). - P. 138-145. 